\title{
Variation of amphibian and reptile composition in forest fragments of Veracruz highlands, Mexico
}

\author{
Angel Ivan Contreras-Calvario, ${ }^{1,2}$ Abigail Mora Reyes, ${ }^{1}$ Rene Avalos Vela, ${ }^{1}$ Jorge L. Castillo \\ Juárez, ${ }^{1}$ and M. Delia Basanta ${ }^{3,4}$ \\ ${ }^{1}$ MESÓFILA. Predio o Instalación para el Manejo de la Vida Silvestre Fuera de su Hábitat Natural (PIMVS). Cd. Mendoza, \\ CP.94740, Veracruz, Mexico. \\ ${ }^{2}$ Instituto Politécnico Nacional, CIIDIR Unidad Oaxaca. Laboratorio de Ecología de Anfibios (ECA). Hornos 1003 , Col. \\ Noche Buena, 71230, Santa Cruz Xoxocotlán, Oaxaca, Mexico. \\ ${ }^{3}$ Universidad Nacional Autónoma de México, Instituto de Biología, Posgrado en Ciencias Biológicas. AP 70-153, C.P. 04510, \\ Ciudad de México, Mexico. \\ ${ }^{4}$ Universidad Nacional Autónoma de México, Centro de Ciencias Genómicas. Cuernavaca, Morelos, Mexico. \\ E-mail: delibasanta@gmail.com.
}

\begin{abstract}
Variation of amphibian and reptile composition in forest fragments of Veracruz highlands, Mexico. The central mountain region of Veracruz is one of the richest areas of herpetofauna in Mexico. The steep topographic gradient of this region is associated with climatic gradients that enable the occurrence of highly diverse herpetofauna communities. We tested differences among habitats to herpetofauna in an urban area, pine forest, oak forest, and riparian forest of municipality Camerino Z. Mendoza, Veracruz, Mexico. We conducted two-day monthly surveys between 2015 and 2017 in 69 sites from fragments of an urban area, riparian forest, Quercus forest, and Quercus-Pinus forest and tested for differences in herpetofauna species among these fragments. We found a total of 11 amphibian and 33 reptile species, and a high composition dissimilarity and species replacement among the sites. Our results amplified significantly the species-records within Camerino Z. Mendoza, and showed a great variation of amphibian and reptile composition among sites, highlighting the current role of these forests as a reservoir for herpetofauna and their importance for future conservation strategies in the region.
\end{abstract}

Keywords: Alfa diversity, beta diversity, herpetofauna, mountain region, richness.

\begin{abstract}
Resumen
Variación de la composición de anfibios y reptiles en fragmentos de bosque del altiplano de Veracruz, México. La región montañosa del centro de Veracruz es una de las regiones con mayor riqueza herpetofaunística de México. El gradiente topográfico de esta región está asociado con diferencias climáticas que permiten la presencia de comunidades herpetofaunísticas muy diversas.
\end{abstract}

Received 09 February 2021

Accepted 09 November 2021

Distributed December 2021 
Analizamos las diferencias en la diversidad herpetofaunística entre un área urbana, bosque de pino, bosque de roble y bosque de ribera del municipio Camerino Z. Mendoza, Veracruz, México. Realizamos censos mensuales de dos días entre 2015 y 2017 en 69 sitios de fragmentos de un área urbana, bosque ribereño, bosque de Quercus y bosque de Quercus-Pinus y analizamos las diferencias de especies de herpetofauna entre estos fragmentos. Encontramos un total de 11 especies de anfibios y 33 de reptiles, y una alta disimilitud en la composición y el reemplazo de especies entre los sitios. Nuestros resultados aumentaron los registros de especies dentro de Camerino Z. Mendoza, y mostraron una gran variación en la composición de anfibios y reptiles entre sitios, destacando el papel actual de estos bosques como reservorio de herpetofauna y su importancia para futuras estrategias de conservación en la región.

Palabras clave: diversidad alfa, diversidad beta, herpetofauna, región montañosa, riqueza.

\begin{abstract}
Resumo
Variação na composição de anfíbios e répteis em fragmentos de floresta das terras altas de Veracruz, México. A região montanhosa de Veracruz central é uma das regiões herpetofaunísticas mais ricas do México. O gradiente topográfico dessa região está associado a diferenças climáticas que permitem a presença de comunidades herpetofaunísticas muito diversas. Analisamos as diferenças na diversidade da herpetofauna entre uma área urbana, uma floresta de pinheiros, uma floresta de carvalhos e uma mata ciliar no município de Camerino Z. Mendoza, Veracruz, México. Entre 2015 e 2017, realizamos censos mensais de dois dias em 69 fragmentos de uma área urbana, uma floresta ribeirinha, uma floresta de Quercus e uma floresta de Quercus-Pinus e analisamos diferenças em espécies entre estes fragmentos. Encontramos um total de 11 espécies de anfíbios e 33 espécies de répteis, e uma grande disparidade na composição e substituição de espécies entre locais. Nossos resultados aumentaram os registos de espécies dentro do município Camerino Z. Mendoza e mostraram uma grande variação na composição de anfíbios e répteis entre sítios, destacando o papel atual dessas florestas como reservatório de herpetofauna e al sua importância para futuras estratégias de conservação da região.
\end{abstract}

Palavras-chave: diversidade alfa, diversidade beta, herpetofauna, região montanhosa, riqueza.

\section{Introduction}

Amphibian and reptile diversity are threatened by land use change and deforestation in several regions around the world (IUCN 2021). For example, urbanization replaces natural habitats with urban infrastructure, which decreases ecological niches for species (McDonnell and Pickett 1993, Hamer and McDonnell 2008), reducing the diversity and abundance of native species, as well as favors invasive fauna (Pickett et al. 2001, McKinney 2006). Currently, $41 \%$ of amphibians and $19 \%$ of reptiles worldwide are in a risk category by the IUCN and land change use and deforestation are among the principal causes (IUCN 2021).
Mexico has a variety of ecosystems that hold the second and seventh largest species richness of reptiles and amphibians in the world, respectively (Flores-Villela and Garcia-Vázquez 2014, ParraOlea et al. 2014, AmphibiaWeb 2021). Most of this diversity is in Veracruz, which is the third state with the greatest herpetofauna diversity of Mexico (Guzmán-Guzmán 2011). This state hosts $25 \%$ (220 spp.) and 27\% (103 spp.) of reptile and amphibian species of the country, respectively. Unfortunately, the transformation of forest habitats into agricultural areas or grazing such as coffee plantations, sugarcane crops and urban areas are threatening the herpetofauna habitats (Murrieta-Galindo et al. 2013a,b, RiveraHernandez 2015). 
The central mountain region of Veracruz is considered one of the richest areas of herpetofauna in the state, harboring approximately 191 species of amphibians and reptiles (AlmarazVidal and Cerón de la Luz 2016). This region is located in eastern Mexico and is part of the mountain system where the eastern end of TransMexican Volcanic Belt and the Sierra Madre Oriental meet. The extremely steep topographic gradient of this region, ranging from sea level to more than $5500 \mathrm{~m}$ a.s.l., is associated with climatic gradients that enable the occurrence of highly diverse communities of herpetofauna (Almaraz-Vidal and Cerón de la Luz 2016) in alpine grasslands, Pinus forest, Abies forest, Quercus forest, xeric shrublands, riparian vegetation, cloud forests, evergreen tropical forest and deciduous tropical forest (RiveraHernández et al. 2019).

Camerino Z. Mendoza municipality is in central Veracruz highlands from 1300 to 2380 $\mathrm{m}$ a.s.1., and harbored different habitats including pine forest, oak forest, and riparian forest. This municipality is within the Cañón del Río Blanco National Park, and includes 12 villages with different demographic growth and proximity to the forests (CONANP 2021). The municipality also belongs to a great industrial region with several effects on natural habitats such as water pollution and overexploitation of natural resources (Rivera-Hernández 2015). The region where Camerino Z. Mendoza is located has been previously studied (OchoaOchoa and Flores-Villela 2006, 2011, AlmarazVidal and Cerón de la Luz 2016, ContrerasCalvario et al. 2019), finding high herpetofauna richness as well as differences in species richness and composition among altitude forests. For example, Almaraz-Vidal and Cerón de la Luz (2016) found in the region 191 species of amphibians and reptiles, of which only 50\% of them are similar between two altitudinal regions of the Pico de Orizaba volcano. Despite the region where Camerino $\mathrm{Z}$. Mendoza is located has been previously studied, to the best of our knowledge, none of these studies have documented the diversity of this municipality along the different environments.

In this study we provide field sampling and records documentation of herpetofauna from Camerino Z. Mendoza, Veracruz, Mexico. Given that urban areas and their closeness to forests may influence amphibian richness, we hypothesized that forests affected by big human populations would show less richness than forests with low or null human impact. To test this, we examined differences in herpetofauna species among areas with different environments (riparian forest, oak forest, pine-oak forest, and an urban area) and different degrees of disturbance due to urbanization. Our results highlight the current role of fragment forests as a reservoir for herpetofauna that could be used for future conservation strategies.

\section{Materials and Methods}

\section{Study Area}

The Camerino Z. Mendoza municipality is located in the highlands region of central Veracruz $\left(18^{\circ} 45^{\prime}-18^{\circ} 49^{\prime} \mathrm{N}, 9^{\circ} 08^{\prime}-97^{\circ} 12^{\prime} \mathrm{W}\right)$ (Figure 1). The region has an annual average precipitation of $900-1600 \mathrm{~mm}$, a tropical wet climate with the lowest temperature at $14^{\circ} \mathrm{C}$ in winter and highest at $20^{\circ} \mathrm{C}$ in the summer season (INEGI 2009, CEIEG 2019). Camerino Z. Mendoza and surrounding areas comprise an admixture of habitats with significantly different forest structure and tree composition, including riparian forest, Quercus forest, Quercus-Pinus forest, and urban areas (Rivera-Hernández 2015) (Figure 1). Additionally, the municipality host four villages with different degree of urbanization: Mendoza City with 45,003 inhabitants and near a riparian forest, La Cuesta with 2,095 inhabitants and surrounded by oak forest, and Necoxtla with 2,890 inhabitants and surrounded by a pine forest (CEIEG 2019). According to the different environments and degree of urbanization that Camerino $\mathrm{Z}$. Mendoza have, we compared the amphibian and 
reptile richness among: a riparian forest (RF) near to Mendoza City dominated by Taxodium mucronatum Ten. (= Taxodium huegelii hort. ex P.Lawson and C.Lawson) (18 $47^{\prime} 44^{\prime \prime}-18^{\circ} 48^{\prime} 15^{\prime \prime}$ N, 07¹0'57"-97¹0'36" W; 1302-1330 m a.s.l.); an oak forest (QF) near to La Cuesta dominated by Quercus $\left(18^{\circ} 47^{\prime} 43^{\prime \prime}-18^{\circ} 47^{\prime} 19^{\prime \prime} \mathrm{N}, 97^{\circ} 10^{\prime} 43^{\prime \prime}\right.$ -97 09'22" W; 1350-2000 m a.s.1.); a pine forest (PF) near to Necoxtla dominated by Pinus patula Schltdl. and Cham., Quercus sp., and Cupressus sp. reforestation $\left(18^{\circ} 47^{\prime} 22^{\prime \prime}-18^{\circ} 45^{\prime} 51^{\prime \prime} \mathrm{N}, 9^{\circ} 09^{\prime}\right.$ $21^{\prime \prime}-97^{\circ} 09^{\prime} 12^{\prime \prime} \mathrm{W}$; 2000-2350 $\mathrm{m}$ a.s.1.); and the urban area of Mendoza City (UA) dominated by non-native species such as Ficus benjamina L., Livistona chinensis (Jacq.) R. Br. ex Mart.,
Jacaranda mimosifolia D. Don, Araucaria heterophylla (Salisb.) Franco, and Eucalyptus globulus Labill. (18 $48^{\circ} 35^{\prime \prime}-18^{\circ} 48^{\prime} 39^{\prime \prime} \mathrm{N}, 97^{\circ} 11^{\prime}$ 46"-97²10'29" W; 1310-1390 m a.s.1.) (Figure $1)$.

\section{Data Collection}

We conducted two-day monthly surveys between 2015 and 2017 in four environments: urban area (UA, 12 sites), riparian forest (RF, 13 sites), Quercus forest (QF, 33 sites), and QuercusPinus forest (QF, 11 sites) (Figure 1). Amphibians and reptiles were actively searched during the day in all microhabitats that might be occupied

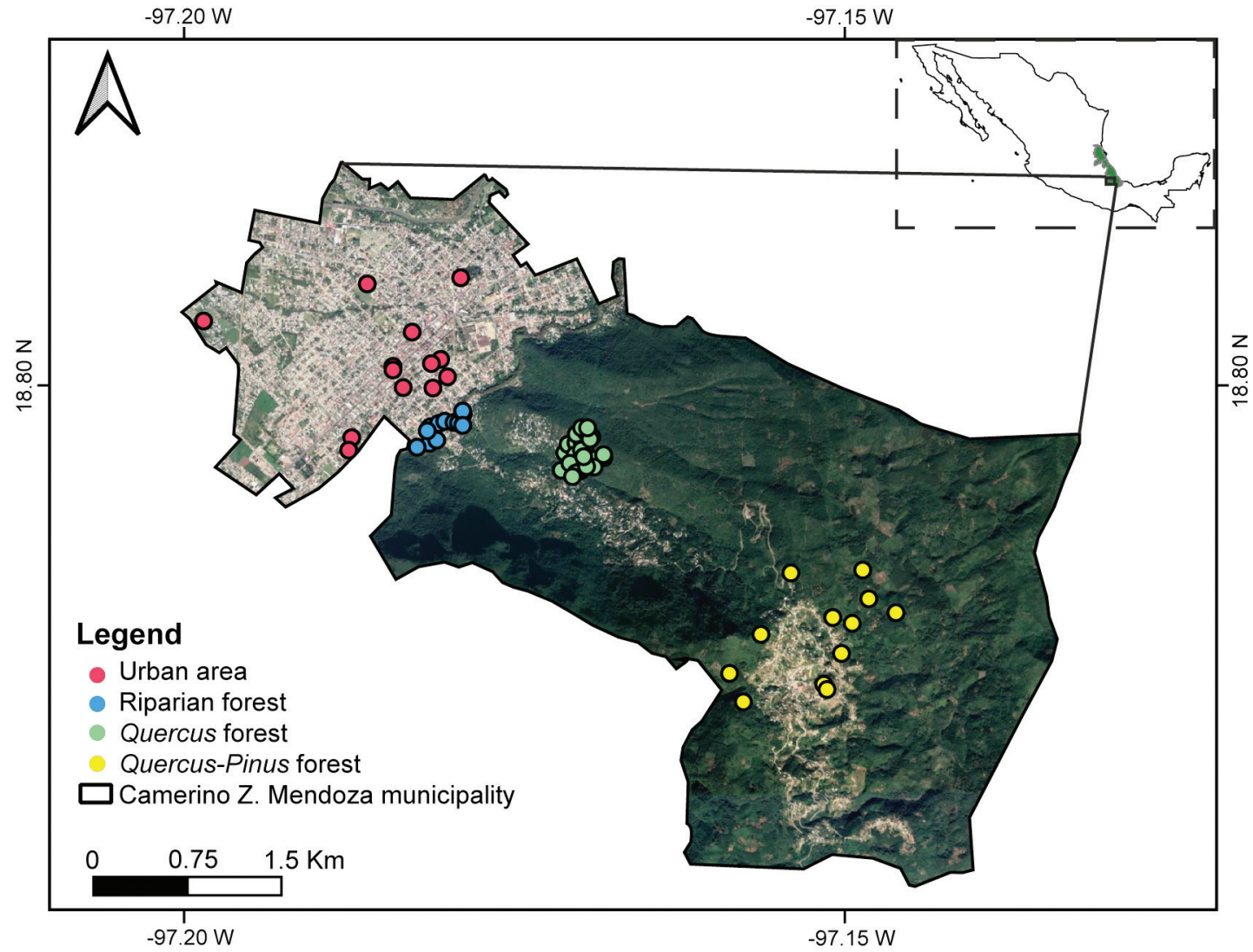

Figure 1. Map of the sites sampled in the urban area, riparian forest, Quercus forest and Quercus-Pinus forest of Camerino Z. Mendoza municipality. 
by amphibians or reptiles. All individuals were collected by hand when encountered for identification, several species were photographed, and all individuals were returned to the collection site. Opportunistically surveys between 2015 and September 2020 also were added to our register.

In addition to our field surveys, we reviewed species reported from this municipality in the VertNet database (http:// portal.vertnet.org/ search), the Global Biodiversity Information Facility database (GBIF https://www.gbif.org/), and the Sistema Nacional de Información sobre Biodiversidad (SNIB) database to which contain records from scientific collections collected in Mendoza municipality.

\section{Data Analysis}

We analyzed the compositional differences among sites through species replacement and species richness differences applying the method proposed by Carvalho et al. (2012). Briefly, the compositional differences were measured at each two sites from the addition of species replacement and species richness differences (Appendix I). The species richness was defined as the number of species found during the study and in electronic databases. Differences in species richness between sites were tested with Kruskal-Wallis test the function 'kruskal.test' in R ( $\mathrm{R}$ Core Team 2019). Replacement was defined as the substitution of $n$ species in a given site by $N$ species in another site. Finally, we obtained an overall measure of compositional dissimilarity among sites using the Jaccard dissimilarity index. To visualize richness and beta diversity, plots were carried using the ggplot2 package (Wickham 2016) in $\mathrm{R}$ ( $\mathrm{R}$ Core Team 2019). Additionally, we determined which species are in a category of risk according to the Red List of Threatened Species (IUCN 2021) and the Mexican law (SEMARNAT 2010), to identify which environments host more species at risk which need conservation strategies.

\section{Results}

The total species for Mendoza was composed of four orders, 16 families, 36 genera and 44 species (33 reptiles and 11 amphibians) (Table 1, Figures 2 and 3). Seven amphibian species and 16 reptile species are endemic to Mexico (Table 1, Appendix II). Additionally, four species were found in our search of the HerpNet, GBIF and SNIB databases (Appendix II). One database species, Scincella gemmingeri (COPE, 1864), was not recorded during our sampling (Appendix II).

The number of species differed between sites, ranging from 13 in the urban area to 25 in Quercus forest (Figure 4A), but it was not statistically significant (Kruskal Wallis test, $\chi^{2}=$ $3, d f=3, p=0.3916)$. The overall compositional dissimilarity among sites was 0.86 on average, ranging from 0.96 to 0.74 . Replacement among sites was 0.64 on average, ranging from 0.87 to 0.39 . The difference in species richness was 0.23 on average, ranging from 0.44 to 0.05 (Figure 4B, Appendix III).

According to the IUCN Red List (2021), 32 species were listed as Least Concern (LC), two as Endangered (EN), two as Near Threatened (NT), one as Vulnerable (VU), and one as Critically Endangered (CR). Meanwhile, according to the Mexican Law (NOM-059SEMARNAT-2010), six species are Subject to Special Protection (Pr), and five are Threatened (A) (Table 1).

\section{Discussion}

Our results show that Mendoza municipality has a great variation of amphibian and reptile composition among sites of riparian forest, oak forest, pine-oak forest and urban area, offering suitable conditions for maintaining a portion of amphibian and reptile species of the region. The 44 amphibian and reptile species found in this study amplified significantly the species-records within Mendoza municipality. This highlights the current role of these forests as a reservoir for 
Table 1. List of amphibians and reptiles found in Camerino Z. Mendoza. Sites where species were detected: UA, urban area; RF, riparian forest; QF, Quercus forest; QPF, Quercus-Pinus forest.

\begin{tabular}{lllllll}
\hline Taxon & UA RF QF QPF IUCN $\begin{array}{l}\text { NOM- Endemic } \\
\text { status }\end{array}$ & $\begin{array}{l}\text { 059 } \\
\text { to Mexico }\end{array}$ \\
\hline
\end{tabular}

\section{AMPHIBIANS}

\section{Bufonidae}

Incilius valliceps (Wiegmann, 1833)

X $\quad$ LC

\section{Craugastoridae}

Craugastor mexicanus (Brocchi, 1877)

\begin{tabular}{|c|c|c|c|}
\hline$X$ & $X$ & LC & - \\
\hline$X$ & $X$ & VU & - \\
\hline
\end{tabular}

Craugastor pygmaeus (Taylor, 1937)

Eleutherodactylidae

Eleutherodactylus cystignathoides (Cope, 1877)

$X$

Eleutherodactylus nitidus (Peters, 1870)

\section{Hylidae}

Rheohyla miotympanum (Cope, 1863)

Smilisca baudinii (Duméril and Bibron, 1841)

\section{Plethodontidae}

Bolitoglossa platydactyla (Gray, 1831)

Isthmura gigantea (Taylor, 1939)

Pseudoeurycea firscheini Shannon and Werler, 1955

\section{RANIDAE}

Lithobates spectabilis (Hillis and Frost, 1985)

\section{REPTILES}

\section{ANGUIDAE}

Abronia graminea (Cope, 1864)

Gerrhonotus ophiurus Cope, 1867

Colubridae

Conopsis lineata (Kennicott, 1859)

Drymarchon melanurus (Duméril, Bibron, and Duméril, 1854)

Ficimia olivacea Gray, 1849

Lampropeltis polyzona Cope, 1860

Mastigodryas melanolomus (Cope, 1868)

Ninia diademata Baird and Girard, 1853

Pituophis deppei (Duméril, 1853)

\begin{tabular}{|c|c|c|c|}
\hline$X$ & $X$ & EN & A \\
\hline$X$ & & LC & - \\
\hline
\end{tabular}

\section{$X$}

NT $\quad \operatorname{Pr} \quad \mathrm{X}$

$X \quad X \quad$ EN Pr

X

$\mathrm{X}$

$X \quad X \quad X$

LC

$x$ 
Table 1. Continued.

\begin{tabular}{|c|c|c|c|c|c|c|c|}
\hline Taxon & UA & $\mathbf{R F}$ & QF & QPF & $\begin{array}{l}\text { IUCN } \\
\text { status }\end{array}$ & $\begin{array}{l}\text { NOM- } \\
059\end{array}$ & $\begin{array}{l}\text { Endemic } \\
\text { to Mexico }\end{array}$ \\
\hline Pliocercus elapoides Cope, 1860 & $x$ & $x$ & $\mathrm{X}$ & & $\mathrm{LC}$ & - & \\
\hline Stenorrhina degenhardtii (Berthold, 1846) & & & $\mathrm{X}$ & & LC & - & \\
\hline Thamnophis conanti Rossman and Burbrink, 2005 & & & & $X$ & - & - & $X$ \\
\hline
\end{tabular}

\section{Dactyloidae}

Anolis sericeus Hallowell, 1856

\section{$X$}

Anolis laeviventris (Wiegmann, 1834)

Anolis tropidonotus Peters, 1863

X

$X$

\section{DiPsADIDAE}

Coniophanes fissidens (Günther, 1858)

Chersodromus liebmanni Reinhardt, 1861

$X$

$\mathrm{X}$

Leptodeira annulata (Linnaeus, 1758)

$X$

X

Leptodeira polysticta (Günther, 1895)

ElaPIDAE

Micrurus diastema (Duméril, Bibron, and Duméril, 1854)

\section{GeKkonidae}

Hemidactylus frenatus Duméril and Bibron, 1836

$X$

LC

KinOSTERNIDAE

Kinosternon integrum Le Conte, 1854

$X$

LC

$\mathrm{LC}$

LC

$\operatorname{Pr}$

$X$

X

LC

\section{Phrynosomatidae}

Sceloporus formosus Wiegmann, 1834

Sceloporus grammicus Wiegmann, 1828

Sceloporus mucronatus Cope, 1885

Sceloporus variabilis Wiegmann, 1834

SCINCIDAE

Plestiodon brevirostris (Günther, 1860)

X LC

Scincella gemmingeri (Cope, 1864)

X

$\begin{array}{ll}X & \text { LC } \\ X & \text { LC } \\ X & \text { LC } \\ & \text { LC }\end{array}$

LC

$\operatorname{Pr}$

\section{TYPHLOPIDAE}

Amerotyphlops tenuis (Salvin, 1860)

X

LC

\section{VIPERIDAE}

Crotalus ravus Cope, 1865

Crotalus triseriatus Wagler, 1830

$X$

LC

A $\quad X$

Metlapilcoatlus nummifer (Rüppell, 1845)

X

LC

$\mathrm{X}$

$x$

LC

A 

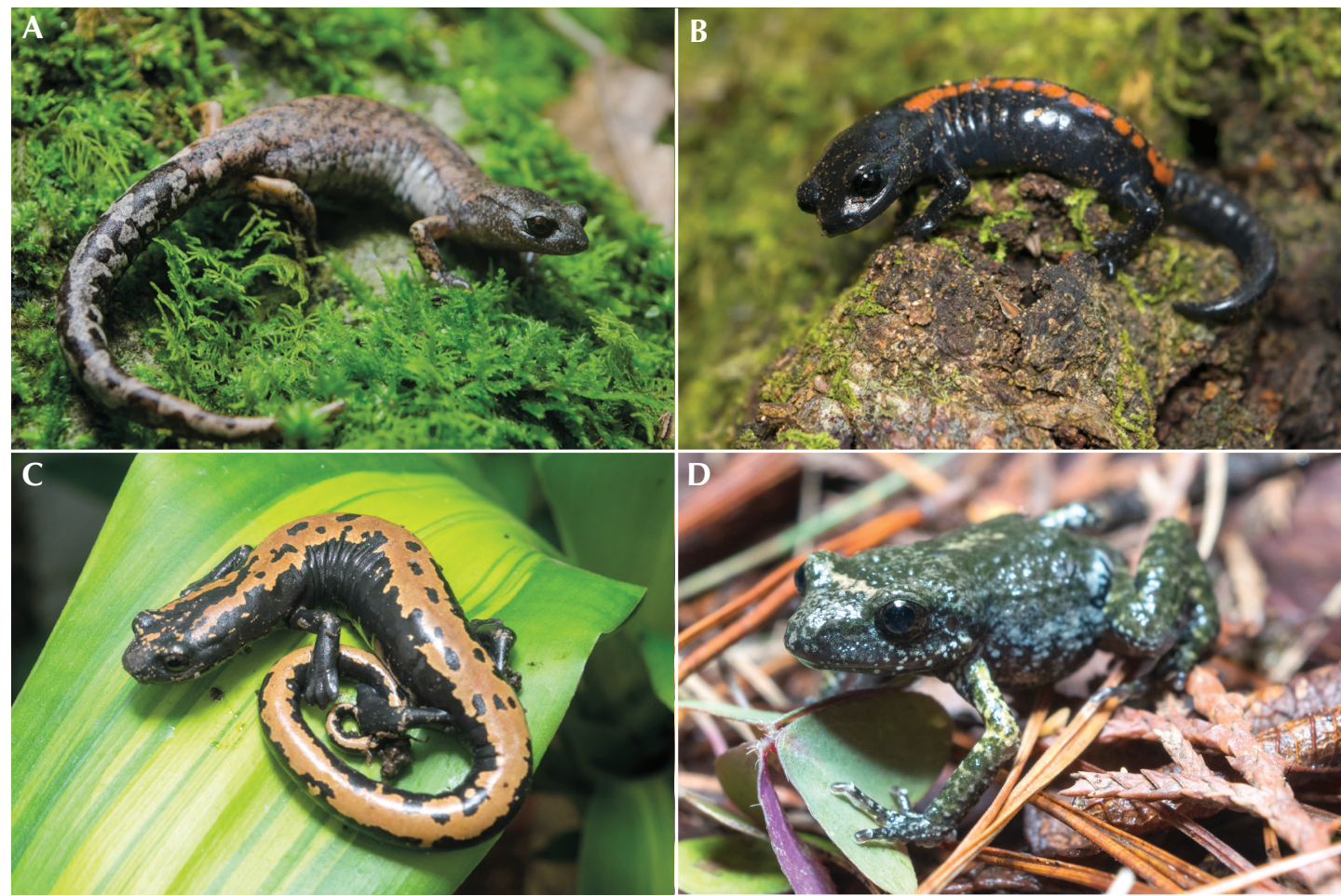

Figure 2. Some amphibians found in Mendoza municipality. (A) Pseudoeurycea firscheini, (B) Isthmura gigantea, (C) Bolitoglossa platydactyla, and (D) Eleutherodactylus nitidus. Photos: JLCJ (A), RAV (B-D)

herpetofauna and their importance for future conservation strategies.

The variation in species richness and species composition among sites suggest that each one offers particular conditions as a product of differences in environments and forest traits. Species richness tends to increase from urban areas to Quercus forest, reaching the highest number of species in this site, and then decreasing in the highest elevation site in the Quercus-Pine forest. However, Quercus forest is one of the most types of vegetation perturbed along Veracruz, and Quercus-Pine has changes in land use and forest species extraction (CastilloCampos et al. 2011). Therefore, the species richness in these areas could be threatened.

The high composition dissimilarity and species replacement among the sites suggest that they are a function of landscape heterogeneity, differences in elevation, and forest management (Meza-Parral and Pineda 2015, Almaraz Vidal and Cerón de la Luz 2016, Aldape-López and Santos-Moreno 2016, Illescas-Aparicio et al. 2016). For example, 29 species are only in one type of vegetation or altitude, and 15 of them are in the Quercus forest. Although the Quercus forest was the environment with more access sites which could have increased the possibility of finding species, this environment has the best forest management in the region, including selective firewood collection such as selection of small branches to leave large logs in the area that may be micro-habitats to herpetofauna (Aldape-López and Santos-Moreno 2016, IllescasAparicio et al. 2016). Other environments such as Quercus-Pine forest have a worse forest management without log size selection and 

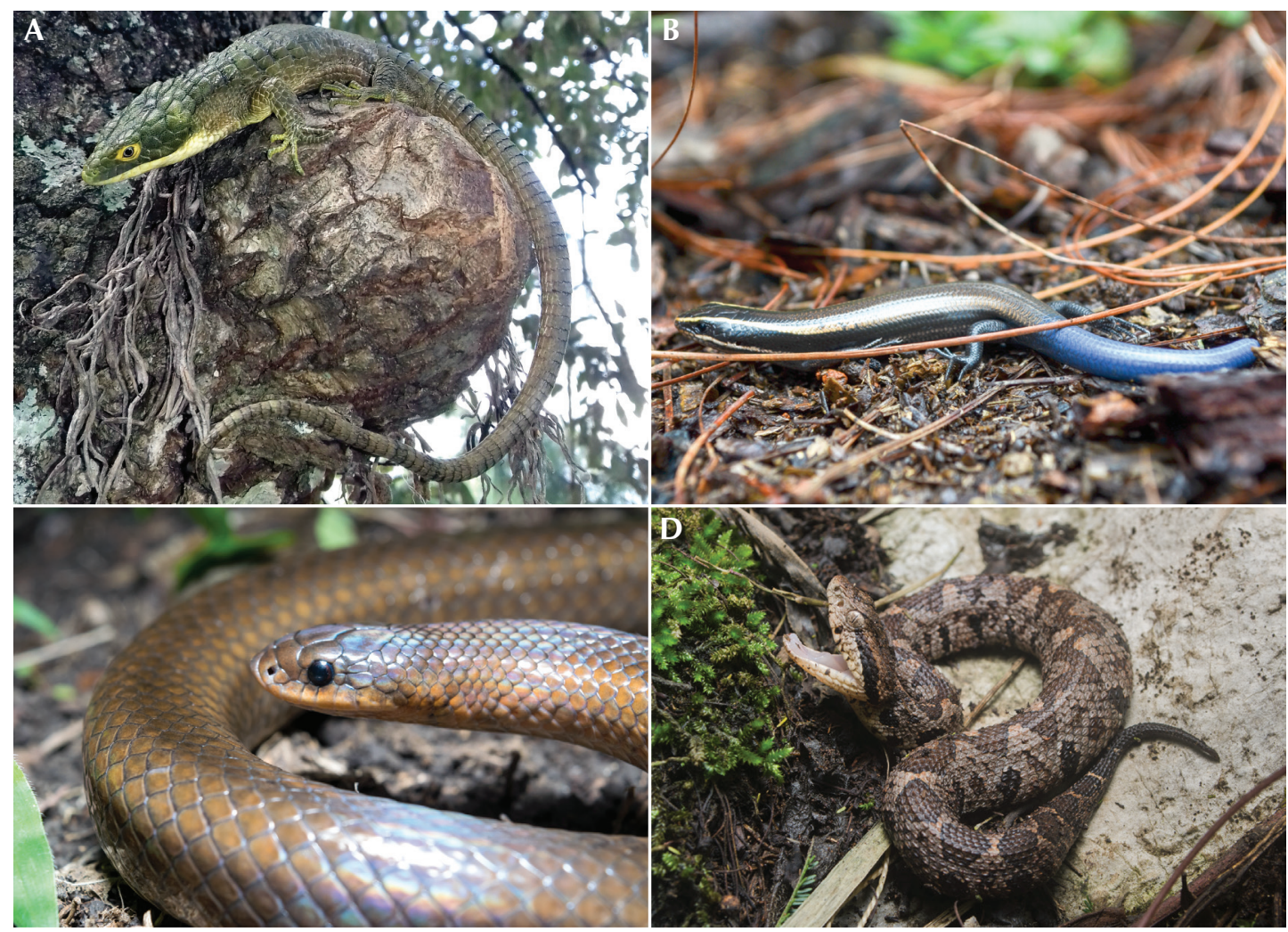

Figure 3. Some reptiles found in Mendoza municipality. (A) Abronia graminea, (B) Plestiodon brevirostris, (C) Stenorrhina degenhartdii, and (D) Metlapilcoatlus nummifer. Photos: ACC (A), RAV (B-C), JLCJ (D).
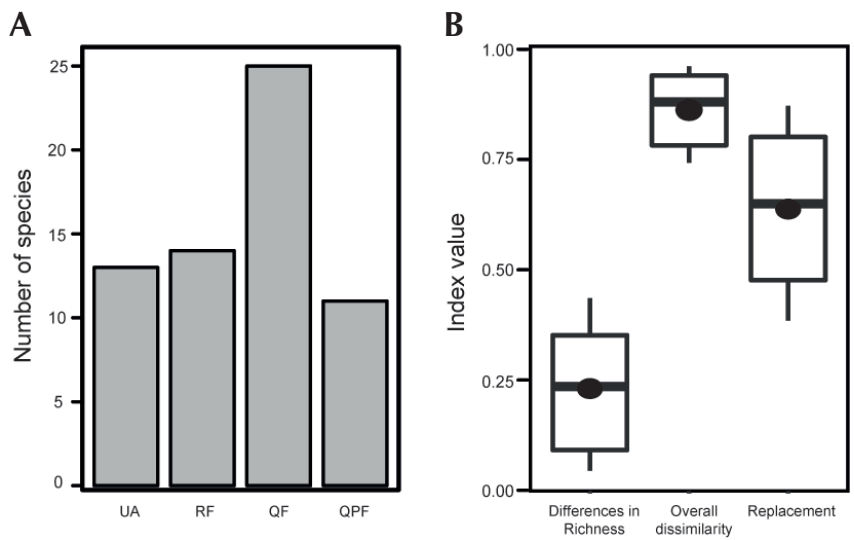

Figure 4. Number of species per site and compositional dissimilarity values between pairs of sites. (A) Herpetofauna richness in four sites of Mendoza municipality. (B) Overall dissimilarity ( $\beta$ cc), replacement $(\beta-3)$, and differences in species richness ( $\beta$ rich) are shown separately. Boxes represent 25 and 75 percentile, the horizontal line is the median, red point the mean, and whiskers are maximum and minimum values. Legend: UA, urban area, (RF) riparian forest, (QF) Quercus forest, (QPF) Quercus-Pinus forest. 
deforestation to grow corn. Thus, the good practices in forest management may be maintaining several habitats for herpetofauna species.

Our results showed that 15 species have wide habitat distribution in more than one type of vegetation. This suggests that the high diversity of Mendoza Municipality is not only in one type of vegetation and is distributed over a wide range of elevations. Previous studies in Veracruz also have found high levels of dissimilarity and replacement in the composition of herpetofauna related to differences in elevation and the degree of heterogeneity (Wake et al. 1992, Pineda and Halffter 2004, Murrieta-Galindo et al. 2013b, Meza-Parral and Pineda 2015, Almaraz-Vidal and Cerón de la Luz 2016). These results indicate that to preserve the herpetofauna of this region, the forest should be protected over a wide range of elevations.

We found 37 species in some category of risk according to the IUCN and the Mexican law (NOM-059). Despite Mendoza municipality being partially within the Rio Blanco National Park, the Quercus-Pine forest is not within this protected area (CONANP 2017). Additionally, anthropogenic activities such as the pollution of Río Blanco river, forest fires, charcoal production, and irregular human settlements are increasing and threatening the species in the region inside and outside the protected area (Rivera-Hernandez 2015). Future studies should incorporate monitoring studies that allow us to know the current state of the populations to incorporate conservation strategies.

\section{Acknowledgments}

We thank Herminio García, Marcelina Martínez, Guillermo Hernández, Ángel Hernández Ramírez, Marisol Rojas Sánchez, Gerardo Torres Cantú, Jair Peña Serrano, and Carlos Pérez for field assistance. We also thank M. García-Castillo for constructive comments regarding the manuscript, and the support of $\mathrm{La}$ Cuesta and Necoxtla communities.

\section{References}

Aldape-López, C. T. and A. Santos-Moreno. 2016. Efecto del manejo forestal en la herpetofauna de un bosque templado en el occidente de Oaxaca, México. Revista de Biología Tropical 64: 931-943.

Almaraz-Vidal, D. and N. M. Cerón de la Luz. 2016. Listado y distribución de la herpetofauna de la zona centrooriental de Veracruz, México. BIOMA 4: 21-34.

AmphibiaWeb. 2021. Electronic database accessible at https://amphibiaweb.org, University of California, Berkeley, USA. Captured on 13 October 2021.

Carvalho, J. C., P. Cardoso, and P. Gomes. 2012. Determining the relative roles of species replacement and species richness differences in generating beta-diversity patterns. Global Ecology and Biogeography 21: 760-771.

Castillo-Campos, G., S. Reyes, and M. E. Abreo. 2011. Flora y vegetación. Pp. 163-180 in A. C. Angón (ed.), La Biodiversidad en Veracruz: Estudio de Estado, Volumen I. Comisión Nacional para el Conocimiento y Uso de la Biodiversidad, Universidad Veracruzana, Instituto de Ecología, AC México.

CEIEG. 2019. Sistema de información municipal, cuadernillos municipales, 2019, Camerino Z. Mendoza. Electronic Database accessible at http://ceieg.veracruz. gob.mx. Sistema de Información Estadística y Geográfica de Veracruz, Gobierno del Estado de Veracruz, México. Captured on 01 December 2020

CONANP. 2017. Ficha general del Área Natural Protegida Cañón del Río Blanco. Comisión Nacional de Áreas Naturales Protegidas. Electronic Database accesible at https://simec.conanp.gob.mx. Captured on 01 December 2020.

CONANP. 2021. Ficha general del Área Natural Protegida Cañón del Río Blanco. Comisión Nacional de Áreas Naturales Protegidas. Electronic Database accesible at https://simec.conanp.gob.mx. Captured on 01 December 2020

Contreras-Calvario, A. I., J. L. Castillo-Juárez, R. AvalosVela, N. M. Cerón de la Luz, and A. Mora Reyes. 2019. Nuevos registros de distribución de cuatro especies de salamandras (Caudata: Plethodontidae) en la región de las altas montañas, Veracruz, México. Revista Latinoamericana de Herpetología 2: 64-70.

Flores-Villela, O. and U. O. García-Vázquez. 2014. Biodiversidad de reptiles en México. Revista Mexicana de Biodiversidad 85: 467-475.

Guzmán-Guzmán, S. 2011. Anfibios y Reptiles de Veracruz, Guía Ilustrada. Veracruz. Consejo Veracruzano de la 
Investigación científica y Desarrollo Tecnológico. 231 pp.

Hamer A. J. and M. J. McDonnell. 2008. Amphibian ecology and conservation in the urbanising world: a review. Biological Conservation 141: 2432-2449.

Illescas-Aparicio, M., R. Clark-Tapia, A. GonzálezHernández, P. R. Vázquez-Díaz, and V. AguirreHidalgo. 2016. Diversidad y riqueza de herpetofauna asociada al bosque de manejo forestal y áreas de cultivo en Ixtlán de Juárez, Oaxaca. Acta Zoológica Mexicana 32: 359-369.

INEGI. 2009. Prontuario de Información Geográfica Municipal de los Estados Unidos Mexicanos. Clave geoestadística 15033. Ecatepec de Morelos, México. 9 pp.

IUCN. 2021. The IUCN Red List of Threatened Species. Version 2020-2. Electronic Database accessible at https://www.iucnredlist.org.

McDonnell, M. J. and S. T. A. Pickett. 1993. Humans as Components of Ecosystems: Subtle Human Effects and the Ecology of Populated Areas. New York. SpringerVerlag. $364 \mathrm{pp}$.

McKinney M. L. 2006. Urbanization as a major cause of biotic homogenization. Biological Conservation 127: $247-260$.

Meza-Parral, Y. and E. Pineda. 2015. Diversidad de anfibios y especies amenazadas en una región neotropical muy transformada en México. PLoS ONE 10: e0121652.

Murrieta-Galindo, R., A. González-Romero, F. LópezBarrera, and G. Parra-Olea. 2013a. Coffee agrosystems: an important refuge for amphibians in central Veracruz, Mexico. Agroforestry Systems 87: 767-779.

Murrieta-Galindo, R., F. López-Barrera, A. GonzálezRomero, and G. Parra-Olea. 2013b. Matrix and habitat quality in a montane cloud-forest landscape: amphibians in coffee plantations in central Veracruz, Mexico. Wildlife Research 40: 25-35.

Ochoa-Ochoa, L. and O. Flores-Villela (eds.). 2006. Áreas de Diversidad y Endemismo de la Herpetofauna Mexicana. México. UNAM-Conabio. 211 pp.

Ochoa-Ochoa, L. and O. Flores-Villela. 2011. Endemismo de la herpetofauna de Veracruz: análisis y problemáticas. Pp. 865-878 in A. C. Angón (ed.), La biodiversidad en Veracruz: Estudio de Estado, Volumen II. Comisión Nacional para el Conocimiento y Uso de la Biodiversidad, Gobierno del Estado de Veracruz, Universidad Veracruzana, Instituto de Ecología, A.C. México.
Parra-Olea, G., O. Flores-Villela, and C. Mendoza-Almeralla. 2014. Biodiversidad de anfibios en México. Revista Mexicana de Biodiversidad 85: 460-466.

Pickett, S. T., M. L. Cadenasso, J. M. Grove, C. H. Nilon, R. V. Pouyat, W. C. Zipperer, and R. Costanza. 2001. Urban ecological systems: linking terrestrial ecological, physical, and socioeconomic components of metropolitan areas. Annual Review of Ecological Systems 32: 127157.

Pineda, E. and G. Halffter. 2004. Species diversity and habitat fragmentation: frogs in a tropical montane landscape in Mexico. Biological Conservation 117: 499-508.

R Core Team. 2019. R: A Language and Environment for Statistical Computing. R Foundation for Statistical Computing, Vienna, Austria. URL: https:// www.R-project.org/.

Rivera-Hernández, J. A. 2015. Flora, vegetación y priorización de áreas de conservación del Parque Nacional Cañón del Río Blanco, Veracruz, México. Unpublished PhD. Dissertation. Instituto Tecnológico de Costa Rica, Costa Rica.

Rivera-Hernández,J. E., R. A. Muñoz-Márquez Trujillo, A. F. Vargas-Rueda, G. Alcántara-Salinas, N. Real-Luna, and R. Sánchez-Páez. 2019. Flora, vegetación y paisaje de la región de las altas montañas de Veracruz, México, elementos importantes para el turismo de naturaleza. Agro Productividad 12: 19-29.

SEMARNAT (Secretaría de Medio Ambiente y Recursos Naturales). 2010. Norma Oficial Mexicana NOM-059SEMARNAT-2010. Protección ambiental. Especies nativas de México de flora y fauna silvestres. Categorías de riesgo y especificaciones para su inclusión, exclusión o cambio. Lista de especies en riesgo. Diario Oficial (Segunda Sección, 30-dic). Electronic Database accessible at: http://www.profepa.gob.mx/innovaportal/ file/435/1/NOM_059_SEMARNAT_2010.pdf. Captured on 01 December 2020.

Wake, D. B., T. J. Papenfuss, and J. F. Lynch. 1992. Distribution of salamanders along elevational transects in Mexico and Guatemala. Tulane Studies in Zoology and Botany, Suppl. 1: 303-319.

Wickham, H. 2016. ggplot2: Elegant Graphics for Data Analysis. New York. Springer-Verlag. 212 pp.

Editor: Eduardo F. Schaefer 
Contreras-Calvario et al.

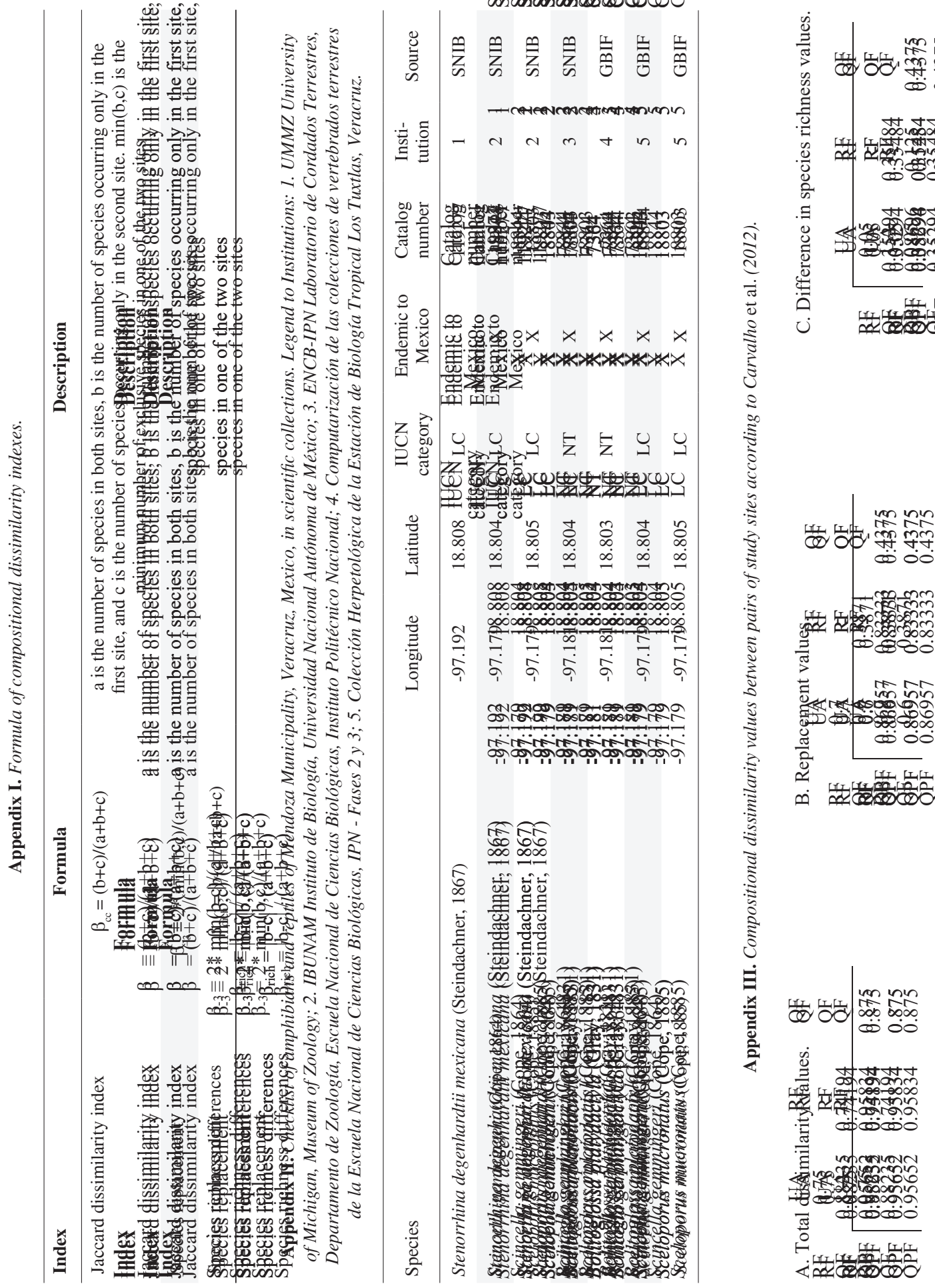

